\title{
D.C. Chemorion
}

\section{TOWARDS A PARTICIPATORY APPROACH TO BIBLE TRANSLATION (PABT) ${ }^{1}$}

\section{ABSTRACT}

It is generally acknowledged that the participation of the receptor community may enhance the community's ownership and acceptability of the translation. In spite of this acknowledgement, individuals and organisations engaged in mother tongue translations of the Bible often involve the members of the receptor community in secondary and non-technical aspects of the translation process. Crucial decisions regarding the nature of the translation are often made by the translation team without adequate input from the community. Part of the reason for non-involvement of the receptor communities in the technical aspects of Bible translation has been the lack of an adequate theoretical framework that explains how the community may fit in the translation process. On the basis of Christiane Nord's functionalist model of translation, this article proposes a "Participatory approach to Bible Translation (PABT)" as a strategy that can be applied to involve the receptor community in technical aspects of the translation.

\section{INTRODUCTION}

Current research in Translation Studies, with regard to functionalist theories of translation, reveals that the client of any given translation plays a primordial role in the determination of the type of translation to be produced. In the arena of Bible translation, the functionalist perspective on the role of the client in the translation process is helpful in re-examining the division of roles between target language communities on the one hand and the sponsoring translation organisations on the other hand. ${ }^{2}$

1 This article is adapted from Dr. D.C. Chemorion's dissertation that was submitted for the award of Doctor of Theology at Stellenbosch University. Cf. Chemorion (2008).

2 In this article, translators are considered as experts in translation matters. Although they may be members of the target language group, they represent the constituency of the organisation that has employed them. In this regard, the writer of this article considers Bible translators as professionals representing the sponsoring Bible translation organisation. The writer of the article also views the role of translators in the Bible translation process as distinct from the role of the larger community who may be the client of the translation.

Dr. D.C. Chemorion, Lecturer in Biblical Studies and Bible Translation, St. Paul's University, Limuru, Kenya, and Research Associate, Department of Old and New Testament, Stellenbosch University. E-mail: dchosefu@stpaulslimuru.ac.ke 
Unlike the case in the past when Bible translators were the sole determinants of the goals/purposes of a translation, today Bible Translation scholars feel that the intended target language community should also play a significant role in deciding on the communicative goals of the translation that is meant for them. ${ }^{3}$ However, the traditional trend in many Bible translation projects in Africa has been characterised with the involvement of members of the community only in secondary and non-technical aspects of the translation process. ${ }^{4}$ Crucial decisions regarding the nature of the translation are often made by the translation team without adequate input from the community. As a result, there tends to be a mismatch between the objectives of the translation from the perspective of the sponsoring organisation and the expectations of the community, which contributes significantly to non-use of vernacular translations of the Bible.

Part of the reason for non-involvement of the receptor communities in the technical aspects of Bible translation has been the lack of an adequate theoretical framework that explains how the community may fit in the translation process. This article has two main aims. The first aim is to highlight a functionalist perspective on the significance of involving the intended audience in the determination of the goals of a translation. Secondly, on the basis of insights drawn from Christiane Nord's functionalist theory, the article presents a "Participatory Approach to Bible Translation" (PABT) as a strategy that may be applied to empower receptor communities in deciding on the communicative goals of the translation that is intended for them.

\section{THE NEED FOR A PARTICIPATORY APPROACH TO BIBLE TRANSLATION}

Bible translation organisations undertaking mother-tongue translations of the Bible emphasise the involvement of local churches in the translation activities as a strategy for successful completion of translation projects. ${ }^{5}$ These organisations hold a general view that the involvement of target language groups in Bible translation activities would boost acceptability and utilisation of the finished products. However, the exact role of the receptor language community in determining the nature and functions of the intended translation remains largely undefined. In many projects that deal with the translation of the Bible into mother tongue in

3 See for example Wendland (2004). Cf. Hill (2006:178ff.)

4 Secondary and non-technical aspects of translation refer to activities that do not contribute to the design of the communicative functions of the translation. The nontechnical roles that are often assigned to target language communities are highlighted in section 2 below.

5 For example, Renju (2001:198) points out that "working with churches" is the most important strategy of the United Bible Societies (UBS). 
Africa, members of the community are involved in non-technical aspects of the translation process such as providing administration for the projects, reviewing translation drafts, raising local support, and marketing of the translated Scripture. However, the translators wield exclusive power in reading/interpreting the source text and shaping the translation to suit the communicative goals as determined by the sponsoring translation organisation.

In their effort to ensure that good quality translations are produced, organisations that sponsor mother tongue translations (for example, the United Bible Societies and the Summer Institute of Linguistics) have employed translation consultants who offer technical supervision during the actual Bible translation process. As a matter of fact, each translation organisation has its own translation philosophy and a particular model of the type of translation which they seek to produce for each of their translation projects. For this reason, one of the key tasks of translation consultants is to ensure that the translation goals set by the sponsoring organisation are achieved. Apart from offering on the job training to translators, translation consultants also ensure that the translation team makes use of the recommended reference resources in order to produce a translation that meets the requirements of the sponsoring translation organisation.

It is undisputable that Bible translation organisations have the necessary expertise to translate the Bible on behalf of communities in need of translations. However, in this era of diversity and multiplicity of Bible versions with different functional emphases, ${ }^{6}$ it is not professionally ethical for translation organisations to produce any type of translation without considering the needs and expectations of the community on whose behalf the translation is done. This also means that as clients, target language communities have the right to hold translation organisations accountable for the type and quality of the translation that is produced. ${ }^{7}$

A consensus that is now emerging among Bible translation scholars is that the translation team and genuine representatives of the target language community should make technical decisions pertaining to the actual product of the translation jointly. In the recent past, some scholars have argued that the intended readership of the translation should be given adequate opportunity to make an input concerning the type of translation that should be produced. For instance, Wendland (2002:183-184; 2004:25-26) observes that in the past, translation theory noted the importance of the intended readership,

6 Cf. Chemorion (2008:1).

7 Cf. Nord's principle of "function-plus-loyalty" as discussed in 3.1 below. The need for target language communities to hold translation organisations accountable for translation products echoes Daniel Patte's call for accountability in biblical exegesis (Cf. Patte 1995:4). 
but often in a unilateral way or even, monolithic sort of way, where the act of communication is viewed as a message transmission, in one direction where the author or translator contributes more or less everything, and the audience simply receives the text, interprets it, and then decides how to respond. Wendland therefore argues that the planners and organisers of Bible translation should not simply anticipate or overlook the intended target audience: "Rather they must make every effort to find out beforehand the specific nature of their listenership/readership - not only their perceived needs, but their actual expressed needs and goals for the translation" (Wendland 2002:184; 2004:26).

As far as the production of a mother tongue translation of the Bible is concerned, Bible translation organisations should not assume that a particular type of translation is what is suitable for the whole community simply because that is the type of translation preferred at the organisational level. In her paper entitled "The challenge of acceptability of the translation by the target language community", Margaret Hill argues that one of the major causes of nonacceptability of mother tongue translations in Africa is the "one product fits all mentality", whereby translation organisations see a particular type of translation as the fulfillment of the goal of Bible translation in every language community (Hill 2005:8). According to Hill, a translation agency should work jointly with representatives of the intended audiences from the target language community to identify a type of translation that is best suited for each audience. ${ }^{8}$

The discussion in above paragraphs shows that there is no question about the need to involve the community in the technical aspects of Bible translation. However, there is a challenge of demonstrating how this can be done practically. In the following section, Christiane Nord's theory of translation is explored because it offers a practical theoretical framework for involving the community in the production of a function-oriented translation.

8 The point raised by Margaret Hill is also reinforced by Harriet Hill (see Hill 2006:179), who states the following: Translators who feel capable of beginning a translation program without input from the community show signs of having a one-product mentality. That is, they believe that there is one standard, correct way of translating the Bible for all audiences. Alternatively, they may recognise the voices involved in designing relevant products, but feel they are best suited to make these decisions on behalf of the community. If translators have either of these perspectives, contact with the churches will be hortative salesmanship attempting to convince them of the translator's perspective rather than offering the pros and cons of various approaches and genuinely putting the decision in the community's hands. 


\section{INSIGHTS FROM NORD'S THEORY OF TRANSLATION}

\subsection{Core values of Nord's functionalist theory}

One of the views held by Nord is that in the real world of translation, the central factor for determining how a translation is done may be found in the question: Does the translation fulfill the function that its initiator(s) ${ }^{9}$ had in mind for it? (Nord 1997:30). In her model of translation, Nord points out that the translator and the initiator of the translation need to work jointly in the formulation of a "translation brief", ${ }^{10}$ which is the key determinant of the type of translation to be produced.

Another outstanding feature of Nord's functionalist approach to translation is the principle of "function-plus-loyalty" (Nord 1997:123ff.). This principle requires the translator to be accountable to both the initiator of the prospective translation and the author of the source text. In observing the "function-plus-loyalty" principle, the translator seeks to produce a translation that complies with the agreed translation brief while at the same time taking care not to betray the communicative intentions of the source text author. The "function-plus-loyalty" principle is therefore meant to serve as an ethical reminder for the translator not to act arbitrarily, but to be committed bilaterally to both the target text requirements and the intentions of the source text author.

\subsection{Participants in the translation process}

Nord (1991:4-11; 2005:5-12) lists essential factors and constituents of the intercultural text transfer and presents them chronologically as: Source text producer, source text sender, source text, source text receiver, initiator, translator, target text, and target text receiver. In her discussion on translating as an interpersonal interaction, Nord narrows down this list to the human actors or participants who take part in the actual translation process. An analysis of her discussion on these participants reveals that the initiator of the translation, the translator, the source text producer (author), and the addressee of the

9 "Initiator" is a technical term, which Nord (1997:20) defines as "the person, group or institution that starts off the translation process and determines its course by defining the purpose for which the target text is needed."

10 A "translation brief" describes the communicative purpose for which the translation is needed. According to Nord (1997:137), the ideal brief provides implicit or explicit information about the intended target-text function(s), the target text addressee(s), the medium over which it is to be transmitted, the prospective place and time and, if necessary, motive of production or reception of the text." 
target text (Nord 1997:20-22) are the main participants in the translation process. Each of these participants is discussed below.

\subsubsection{Initiator of the translation}

According to Nord (1991:8; 2005:9), the initiator plays a crucial role in the process of translation and is described as the factor that starts the process and determines its course. In her schematic representation of the translation process, Nord explains that in the professional practice of intercultural communication, translators rarely start working on their own accord. They are usually called upon to do so by a client or initiator who needs a translation for a particular purpose (Nord 1997:30). Nord states that in an ideal situation, the initiator presents a set of translating instructions (translation brief) to the translator, which serve as a guide to the translator in the translation process. ${ }^{11}$ This means that the initiator is the prime mover of the translation process.

\subsubsection{Translator}

Besides the initiator of the translation, the other most significant participant in the translation process is the translator. According to Nord (1991:10; 1997:21; 2005:10), translators are ostensibly the experts in the translational action and they should be responsible for carrying out the commissioned task and for ensuring the result of the translation process. During the translation process, the translator receives both the translation brief and the source text, which become the basis for the production of the target text.

Although the initiator provides essential information regarding the purpose of the translation, the translator is the one who produces the technical statement on the skopos of the target text (Nord 1991:1, 2005:10). Apart from helping the initiator to state the skopos of the translation in technical language, the translator is responsible for the final product of the translation. Having established the skopos of the translation in technical terms, the translator proceeds to produce the expected target text. However, the translator needs to have certain abilities in order to carry out the translation task effectively. According to Nord (1999) the basic requirements for a translator are the ability to retrieve information from the source text and the ability to process a given amount of information in such a way as to produce a functional text that is apt to fulfill the requirements of the translation brief. ${ }^{12}$ Nord $(1991: 11 ; 2005: 12)$ explains that ideally, the translator

11 The translating instructions consist of a more or less explicit description of a prospective target situation, which Nord refers to as "skopos" of the target text. Cf. Nord (1991:8; 2005:10). 
has a perfect command of both the source and the target culture (including languages), and possesses a transfer competence which comprises the skills of text reception, text production, and research, as well as the ability to synchronise source text reception and target text production.

\subsubsection{Source text producer}

The other significant participant in the process of translation in view of Nord's functionalist model is the producer of the source text. This is the participant that produced the text that serves as the source material that needs to be translated into the target language (Nord 1997:20). The role of the source text producer is closely related to that of the sender, who is defined as a person, group or institution that uses the text in order to convey a certain message (Nord 1997:21). According to Nord (1997:85), in original literature, the sender and the text producer may be one and the same person, though sometimes they are separate participants. In a normal translation situation, the source text producer is not physically present but his/her presence is felt indirectly through textual features. For a translator to produce a functional translation, s/he must draw a balance between the communicative intentions of the source text sender and the stated expectations of the initiator.

\subsubsection{Addressee of the translation}

With reference to the work of Holz-Mänttäri, Nord (1997:22) describes the addressees of the target text as a decisive factor in the production of the target text. Just like the addressees of the source text, the addressees of the target text are relevant in the translation process for specifying the purpose of the translation (Nord 1997:20). The information concerning the nature of the addressee needs to be supplied in the translation brief. A distinction should, however, be made between the addressees of the target text and recipients of the target text. Whereas the addressees are the audience for whom the translation is designed, the receivers of the translation include those for whom the translation was actually not meant for (Nord 1997:22). In other words, addressees are the people whose translation needs and expectations are known to the transla-

12 Vermeer who shares the same view with Nord states the following: "As regards the translator himself: experts are called upon in a given situation because they are needed and because they are regarded as experts. It is usually assumed, reasonably enough, that such people 'know what it is all about': they are thus consulted and their views listened to. Being experts, they are trusted to know more about their particular field than outsiders" (Vermeer 2000/2004:226). 
tor. However, the final recipients of the target text may include people who are not in focus when the skopos of the translation is drawn.

\section{NORD'S FUNCTIONALIST THEORY AS A BASIS FOR THE COMMUNITY'S PARTICIPATION IN TRANSLATION}

\subsection{The role of the target language community}

As seen in section 3.2.1 above, Nord identifies the initiator as the client who expresses the need for a translation to the translator and supplies the translation brief which serves as the guide to translation decisions. In Nord's view, the role of the initiator is flexible. With reference to the communicative roles of source text producer, source text sender, source text recipient, initiator, translator, and target text recipient, Nord (1991:6; 2005:7) states,

\footnotetext{
these are communicative roles which can, in practice, be represented by one and the same individual. For example, the source text author himself, the target text recipient, or even the translator can act as the initiator of the translation.
}

Given this flexibility of communicative roles, the receptor language community, through its representatives, has two possible roles to play in the process of translation. The community may participate in the translation process as the addressee or as the "initiator-cum-addressee". Each of these roles has significant implications for a mother tongue translation project as explained below.

If, on the one hand, the target language community is only an addressee of a particular translation, it means that the target language community is not a major decision maker in the translation process. From the perspective of Nord's functionalist model, we could refer to the addressee as a passive participant in the translation process. Unlike the participant playing the role of the initiator who charts the way for translation process, the one playing the role of the addressee does not directly participate in the decision-making process. In this case, the target language community's involvement and commitment to the goals of the translation may be very minimal because other agents, apart from the target language community, control the conceptualisation of the project and its implementation.

If on the other hand, the target language community is the "initiator-cumaddressee" of the translation, then it means that the target language community is the owner of the vision for its own translation project. In terms of Nord's model of translation, this means that the target language community is the one that designs the translation brief in conjunction with the translator. As 
the carrier of the vision of the translation, the target language community is expected to be involved in planning, implementing, and evaluating the translation process. Because of this involvement, one would expect the target language community to have a high sense of ownership of the translation project and its products. The advantage of having the target language community play the role of the initiator is that the translator will also be in a better position to understand and take into account the subjective theories of the target language community. The following section describes a participatory approach to Bible translation, which shows how a community in need of a mother tongue translation may be involved in the technical design and production of the translation.

\subsection{An outline of the Participatory approach to Bible translation (PABT)}

The PABT approach aims at the active involvement of the target language community in the design of the translation brief, which guides the actual process of Bible translation. In this approach the most important participants in the translation process are: the target language community, the sponsoring translation organisation, and the source text author. As it has been discussed in the previous section, the target language community in the PABT approach is allocated the role of "initiator-cum-addressee" for the translation. There are three important steps to be followed in involving members of the community in the technical aspects of translating the Bible into mother tongue. These steps are: the engagement step, the source text analysis step, and the transfer step. Each of these steps is discussed below.

\subsubsection{The engagement step}

The goal of the translator (translation organisation/translation team) at this initial step needs to be to establish a good rapport and to involve the community in the formulation of a translation brief. Ideally this begins when representatives of the target language community and the translation organisation are introduced to each other. There is no fixed procedure for the introduction. In some situations representatives of the community may approach the translation organisation to make a request for a translation. But in other situations, the translation organisation may visit the community to initiate talks with the view of creating awareness for the need of a translation. When formal introduction has been done and a rapport has been created, the translation process should move to the second part of the engagement step, which is concerned with the formulation of a translation brief. 
The nature of client participation in the formulation of a translation brief varies from one translation situation to another. It also depends on the nature of the translation task and the ability of the client to provide clear translation instructions. Nord (1991:11) indicates that there are two possible ways by which a translation brief can be formulated. Either the initiator provides the translator with an explicit translation brief or the translator infers a suitable translation brief from the translation situation (Nord 1997:60). In situations where clients are able to provide explicit translation briefs, the task of the translator is simply to negotiate with the initiator over the terms of service for producing the translation. In many cases, however, clients provide implicit translation briefs, but they are unable to formulate the translation briefs on their own (Nord 1997:30). Such situations make it necessary for the translator to carry out a translation-oriented research aimed at analysing the prospective target text situation and its implications for the intended translation.

In the case of a mother tongue translation project, it may not be possible for the receptor language group to provide an explicit translation brief. For this reason, the translator should carry out a translation-oriented research aimed at collating information that can be used to formulate a translation brief. Among other issues, the translator should seek information about essential issues that need to be taken into consideration when doing translation. These include: the history and character of the church in the area, the level of Christian maturity, the culture of the people and their worldview, and issues pertaining to the spoken language, orthography and literacy. Such data would assist the translator to gauge the nature of the translation needs and how best to tackle them.

Part of the translation-oriented research is to create a forum where members of the language group can express their views about the prospective translation. Since it is not possible to involve every member of the community in the formulation of a translation brief, it is necessary to have representative participation of the community in the formulation of the brief. The translator (or the sponsoring translation organisation) should identify people who can represent the community in the discussion of the goals of translation. The representatives of the language community need to be drawn from all categories of people within the community. Such representatives should be people chosen by the community to act authentically on behalf of the whole community, and to provide regular feedback on project development. The views of such representatives should reflect the wishes of not only the scholars and clergy, but also the ordinary Christians in the language group. ${ }^{13}$ It is important to identify the representatives through a democratic and fair process in order to have a fair representation of all people in the community.

13 The ordinary Christians need to be represented because they are the ultimate users of the version to be produced. 
When the list of representatives has been drawn, the translator may invite them for a translation workshop in which the representatives are given room to discuss the goals and objectives of the intended translation. This can be achieved by answering questions such as the following: What is the purpose/ skopos of the translation or why is the translation needed? Which is the preferred source text? Which style of translation is preferred? Which is the preferred formatting style? Who shall be the primary audience? Which language/dialect should be used in the transfer process? Who is to carry out the task? Where shall the required resources come from? Which procedure will be followed in evaluation? When is the project expected to come to an end? Such questions are helpful in laying down a firm foundation for a major translation project.

The aim of a participatory translation-oriented research should be to help the translator/translation organisation to understand the translation needs from the general perspective of the community. It is therefore very important for the translator to study all the data that has been collected, including the information generated during the translation workshop. All information should be put together and analysed. On the basis of the analysed data, the translator/translation team can therefore formulate a translation brief which needs to include the following: the type of the translation and its communicative goals, the intended addressees, the medium and process of translation, the time of production and the place of text reception. The translation brief formulated in this manner becomes the voice of the community in determining the nature of the translation.

\subsubsection{The source text analysis step}

Once the requirements of the translation have clearly been put in the translation brief, the translation process can move to the second step, which is the "source text analysis". In this stage, the translator/translation team studies the source text in context to determine the meaning intended by the source text author. The source text needs to be analysed in view of the translation brief. ${ }^{14}$ Ideally, a translator reads the translation brief before he/she reads the source text. This means that the time a translator reads the source text, his/her reception process would have been affected by the translation brief thereby causing the reading process to be tuned to the requirements of the translation brief (Nord 2005:12). During the process of analysis, the translator studies the source text while keeping an eye on the requirements of the translation brief. In this case, the translation brief helps the translator to focus on the source text elements that may need to be retained, left out, or modified to suit the needs of the target language community.

14 During source text analysis, the target language community, as the initiator of the translation is not physically present but it is represented by the translation brief which the translator consults regularly during the study of the source text. 
By constantly looping back to the translation brief, the translator is able to read and interpret the source text while at the same time considering interests of the community. It is also important for the translator/translation team to adhere to Nord's ethical rule of "function-plus-loyalty" in order to ensure that the needs of the target audience are adhered to without violating the intentions of the source text author. After the analysis of the source text, the translation process enters the third step of actual drafting of the translation as described below.

\subsubsection{Transfer step}

The third step of a participatory translation process is the "transfer" step. Here the translator applies translation skills to render the biblical message into the receptor language in view of the understanding arrived at during the source text analysis step. Although the initiator of the translation is not physically present at this step, the transfer process is also participatory in the sense that the translator produces the target text with regard to the expectations of the initiator as stated in the agreed translation brief. ${ }^{15} \mathrm{It}$ must be emphasised that the translator does not transfer the text for his/her own sake but on behalf of the initiator (Nord 2005:12). It is also important that participatory translation takes place when the translator deliberately shapes the textual elements of the target text in such a way that they become coherent with the expectations of the target audience as contained in the translation brief. After the translation draft has been produced it should be taken back to the community's representatives for their evaluation in accordance with the translation brief. Any translation errors noticed should be corrected before the translation is published. The model drawn below shows the proposed participatory approach to Bible translation.

15 According to Lesch (1999:93), "community translation" takes place when the translator prioritises the needs of the community, or when the translator represents the reader's perspective, during the translation process. Similarly, the production of a translation draft can be said to be participatory when the translator keeps looping back to the translation brief to ensure that the translation is in line with the expectations of the target language community. 


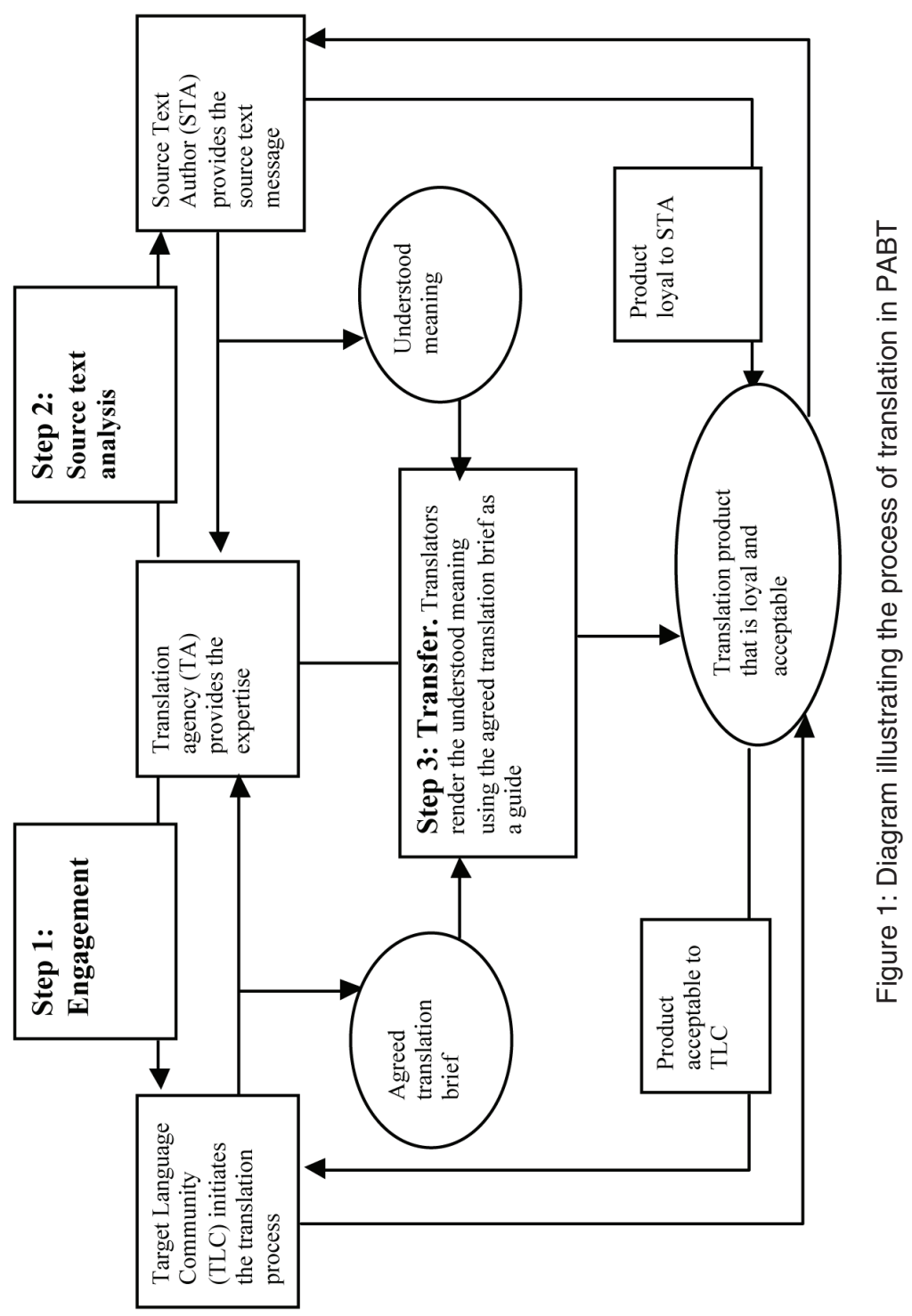




\section{CONCLUSION}

In this article, it has been pointed out that Nord's functionalist model of translation provides a framework whereby a receptor language group could be involved in the translation process. With insights drawn from Nord's functionalist model, the writer of this article has formulated a Participatory approach to Bible translation (PABT), which may be applied to formulate a translation brief from the perspective of the community. Since a translation brief is a tool that specifies the nature of the translation, the participation of the community in the formulation of the translation brief becomes an effective way of involving the community in the technical aspects of Bible translation. It must be emphasised that involvement of the community in the formulation of the translation brief empowers the community to decide on the type of the prospective translation. If that is done the resulting translation would have higher chances of being acceptable to the community because it is based on the community's translation needs and specifications. The writer of this article successfully used the PABT approach to translate the book of Jonah into the Sabaot language ${ }^{16}$ However, the approach needs to be tested in different contexts.

\section{BIBLIOGRAPHY}

CHEMORION, D.C.

2008. Translating Jonah's narration and poetry into Sabaot: Towards a participatory approach to Bible translation. Unpublished Dissertation. University of Stellenbosch.

HILL, $\mathrm{H}$.

2006. The Bible at cultural crossroads: From translation to communication. Manchester: St. Jerome Publishers.

HILL, M.

2005. The challenge of acceptability of the Translation by the target language community. Paper presented at OTSSA Congress on Biblical Interpretation in Africa. Pietermaritzburg, South Africa, September 19-23, 2005. Unpublished manuscript.

LESCH, $\mathrm{H}$.

1999. Community translation: Right or privilege? In: M. Erasmus, Liaison interpreting in community (Pretoria: Van Schaik), pp. 90-98.

MUNDAY, J.

2001. Introducing translation studies. London: Routledge.

16 See Chemorion 2008. 
NAUDÉ, J.A.

2002. An overview of recent developments in translation studies with special reference to the implications for the Bible. In: J.A. Naudé \& C.H.J. van der Merwe (eds.), Contemporary translation studies and Bible translation: A South African perspective. Acta Theologica, Supplementum 2 (Bloemfontein: University of the Free State), pp. 44-65.

Nord, C.

1991. Text analysis in translation: Theory, methodology and didactic application of a model for translation-oriented text analysis. Amsterdam: John Benjamins.

1997. Translating as a purposeful activity: Functionalist approaches explained. Manchester, U.K.: St. Jerome Publishing.

1999. Translating as a text production activity. [Online]. Retrieved from: http://www. humnet.unipi.it/traduzione_letteraria/download/bruti/Nord_Translatingtextproduction.pdf. [2006, 1 December].

2005. Text analysis in translation: Theory, methodology and didactic application of a model for translation-oriented text analysis. 2nd ed. Amsterdam, New York: Radopi.

PATte, D.

1995. Ethics of biblical interpretation: A re-evaluation. West Minister: John Knox Press.

Renju, P.

2001. United Bible Societies' strategies for Old Testament translation in Africa. In: M.N. Getui et al. (eds.), Interpreting the Old Testament in Africa (Nairobi: Acton Publishers), pp. 195-215.

Vermeer, H.J.

2000/2004. Skopos and communication in translational action. In: L. Venuti (ed.), The translation studies reader. 2nd ed. (London: Routledge), pp. 227-238.

WendLAnd, E.R.

2002. Towards a literary translation of the Scriptures with special reference to a poetic rendition. In: J.A. Naudé \& C.H.J. van der Merwe (eds.), Contemporary translation studies and Bible translation: A South African perspective. Acta Theologica, Supplementum 2 (Bloemfontein: University of the Free State), pp. 164-201.

2004. Translating literature of Scripture: A literary rhetorical approach to Bible translation. Dallas, Texas: SIL International.

Keywords

Bible translation

Receptor communities

Participatory approach

Model of translation
Trefwoorde

Bybelvertaling

Ontvangergemeenskappe

Deelnemende benadering

Vertaalmodel 